\title{
Characterization of the adaptive response of grapevine (cv. Tempranillo) to UV-B radiation under water deficit conditions
}

\author{
J. Martínez-Lüscher ${ }^{a, c, d}$, F. Morales ${ }^{b, a}$, S. Delrot ${ }^{c, d}$, M. Sánchez-Díaz ${ }^{a}$, E. Gomès ${ }^{c, d}$, J. \\ Aguirreolea $^{a}$, I. Pascual ${ }^{\mathrm{a}}$
}

${ }^{a}$ Grupo de Fisiología del Estrés en Plantas (Dpto. de Biología Ambiental), Unidad Asociada al CSIC, EEAD, Zaragoza e ICVV, Logroño. Facultades de Ciencias y Farmacia, Universidad de Navarra, Irunlarrea 1, 31008, Pamplona. SPAIN

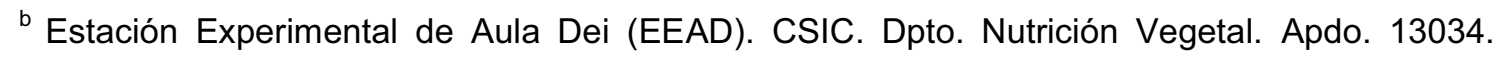
50080. Zaragoza. SPAIN

' INRA, Institut des Sciences de la Vigne et du Vin, UMR1287 EGFV, 210 Chemin de Leysotte. 33883 Villenave D'Ornon. FRANCE

${ }^{\mathrm{d}}$ University of Bordeaux, Institut des Sciences de la Vigne et du Vin, UMR1287 EGFV, 210 Chemin de Leysotte. 33883 Villenave D'Ornon. FRANCE

\section{Corresponding Autor:}

Inmaculada Pascual Elizalde

Grupo de Fisiología del Estrés en Plantas (Dpto. de Biología Ambiental), Unidad Asociada al CSIC, EEAD, Zaragoza e ICVV, Logroño.

Facultades de Ciencias y Farmacia

UNIVERSIDAD DE NAVARRA

C/ Irunlarrea, 1

31008 Pamplona (SPAIN)

Telephone: +34948 425600 Ext. 806668/806227

FAX number: +34948425619

e-mail: ipascual@unav.es 


\section{ABSTRACT}

This work aims to characterize the physiological response of grapevine (Vitis vinifera L.) cv. Tempranillo to UV-B radiation under water deficit conditions. Grapevine fruit-bearing cuttings were exposed to three levels of supplemental biologically effective UV-B radiation $(0,5.98$ and

$9.66 \mathrm{~kJ} \mathrm{~m}^{-2} \mathrm{day}^{-1}$ ) and two water regimes (well watered and water deficit), in a factorial design, from fruit-set to maturity under glasshouse-controlled conditions. UV-B induced a transient decrease in net photosynthesis $\left(A_{\text {net }}\right)$, actual and maximum potential efficiency of photosystem II, particularly on well watered plants. Methanol extractable UV-B absorbing compounds (MEUVAC) concentration and superoxide dismutase activity increased with UV-B. Water deficit effected decrease in $A_{\text {net }}$ and stomatal conductance, and did not change non-photochemical quenching and the de-epoxidation state of xanthophylls, dark respiration and photorespiration being alternative ways to dissipate the excess of energy. Little interactive effects between UV-B and drought were detected on photosynthesis performance, where the impact of UV-B was overshadowed by the effects of water deficit. Grape berry ripening was strongly delayed when UV-B and water deficit were applied in combination. In summary, deficit irrigation did not modify the adaptive response of grapevine to UV-B, through the accumulation of MEUVAC. However, combined treatments caused additive effects on berry ripening.

Key words: photosynthesis, phenology, UV-B radiation, UV-B absorbing compounds, Vitis vinifera L., water deficit 


\section{INTRODUCTION}

Mediterranean vegetation is often exposed to high fluence rates of UV-B radiation (280-315 $\mathrm{nm}$ ), because of cloudless summer sky. In addition, the absence of precipitation is considered as a major limiting factor for plant growth and development during the summer months in this area . In many regions, reduced water availability is frequently accompanied by increased UV-B radiation levels [1]. Predicted scenarios of climate change over the next decades include a pronounced decrease in precipitation, especially in the warm season, thus increasing the probability of extreme drought events in the Mediterranean area [2]. Besides, changes in mean cloudiness may affect the levels of solar radiation, including UV-B, reaching Mediterranean ecosystems in the near future [3].

The effects of UV-B radiation on leaf physiology have been extensively studied. They include changes on leaf ultrastructure and anatomy, reduction in the concentration of photosynthetic pigments and photosynthetic capacity, altered plant phenology and reduction of plant biomass production [4]. In addition, when exposed to UV-B, plant cells usually produce reactive oxygen species (ROS), regardless of the dose applied, as a result of the disruption of metabolic activities or by the activation of membrane-localized NADPH-oxidase [5]. In order to cope with oxidative damage, plants activate their antioxidant metabolism. Increases in superoxide dismutase (SOD), catalase (CAT), ascorbate peroxidase (APX) and guaiacol peroxidase (GPX) activities have been found in many UV-B exposure studies [5]. Another of the direct UV-B adaptive mechanisms best studied is the biosynthesis of UV-B absorbing compounds, mainly flavonoids. UV-B responsive flavonoids located in the vacuoles of epidermal cells have the potential to attenuate the penetration of UV-B radiation [6]. In addition, dihydroxy flavonoids located in the chloroplasts of mesophyll cells may have a central role in the antioxidant defense system, inhibiting the generation of ROS and reducing ROS once they have formed [7], thus avoiding oxidative damage to DNA, structural proteins, lipids and other cellular compounds. The chloroplast-located flavonols may have a very peculiar location which is of increasing significance when excess of radiant energy-induced depletion of key components of the antioxidant network system allows the diffusion of ROS out of the chloroplast [7]. 
Evidence of interaction between UV-B exposure and drought stress in plants has emerged in recent years. A series of similar defense mechanisms, as well as adverse changes, leading to disruption of physiological processes, growth inhibition and yield reduction, take place in plants exposed to single action of water deficit and UV-B radiation [1]. Therefore, combined action of water deficit and UV-B radiation can modify the response patterns. Previous studies show that UV-B radiation can interact with water deficit to induce protective mechanisms, i.e. increased levels of UV-B absorbing compounds (flavonoids) and antioxidant enzymes (SOD, CAT and APX), osmolyte accumulation (i.e. proline), increased leaf cuticle thickness or reduced stomatal conductance. These responses may substantially decrease UV-B and/or drought sensitivity when both factors are applied in combination [8, 9]. Furthermore, both UV-B and water deficit cause the generation of ROS, nitric oxide, and induce the synthesis of abscisic acid, ethylene, jasmonic and salicylic acid. These molecules, controlling plant reactions to both water deficit and UV-B applied separately, may also be involved in cross-talk under their combined actions $[1,10]$. Nevertheless, responses are not always consistent between studies, thus leading in some cases to contradictory results. This is the case of Sullivan and Teramura [11], Duan, et al. [12] and Bernal, et al. [13], who found few significant interactions between UV-B and water stress on plant growth and photosynthetic activity. On the other hand, when UV-B or water deficit, applied alone, causes damages, their combined action usually became more detrimental. For instance, combined stresses treatment led to the inhibition of soluble sugars accumulation, restricting the capacity for osmotic adjustment, which caused negative additive effect on rosette growth of Arabidopsis thaliana [14]. Additive negative effects on the growth of grapevine and willows have also been reported $[15,16]$. Thus, the coincidence of water deficit and UV-B radiation, depending on their intensity, duration and sequence of occurrence, may activate mechanisms allowing plants to cope under stress conditions or enhance harmful effects. Such contrasting responses highlight the capacity for interaction between water deficit and UV-B, but clearly demonstrate the need for further studies of these interactive responses.

The aim of this work was to characterize the response of grapevine cv. Tempranillo to UV-B radiation under water deficit conditions, focusing on plant development, photosynthetic performance, antioxidant enzymes and UV-B absorbing compounds. Although the cultivar Tempranillo, in particular, is probably well adapted to relatively high UV-B irradiance $[17,18]$, 
the study of the interactive effects of UV-B and water deficit may help to understand the acclimation response of grapevine to UV-B within a climate change context, where the influence of other co-occurring abiotic stress factors can modulate grapevine responses to UV-B radiation. To this end, the fruit-bearing cutting model system for grapevine (fruiting plants developed from rooted cuttings) was used, providing a feasible system to study the impact of stress factors effects on grapevine physiology, without other confounding environmental influences. This model allows the development of vegetative (roots, leaves and shoots) and reproductive (inflorescences and clusters) organs as for the vineyard grapevines, under fully controlled environmental conditions. Fruit-bearing cuttings respond like vineyard plants to different cultural factors $[19,20]$. Indeed, the fruit-bearing cuttings model has been previously useful in the evaluation of the physiological response of grapevine to environmental or developmental factors [17, 20-22].

\section{MATERIAL AND METHODS}

\subsection{Plant material and growth conditions}

Fruit-bearing cuttings of Vitis vinifera L. cv. Tempranillo were produced as described in Martínez-Lüscher, et al. [17]. Briefly, three-node segments of grapevine cv. Tempranillo were collected, from Station of Viticulture and Enology of Navarra (Olite, Spain). Rooting was induced using indol butiric acid in a heat-bed $\left(27^{\circ} \mathrm{C}\right)$ kept in a cool room $\left(5^{\circ} \mathrm{C}\right)$ in darkness. When cuttings developed enough roots, they were transplanted to $6.5 \mathrm{~L}$ pots containing 1:1 soil:peat $(v / v)$. Only one flowering stem was allowed to develop on each plant. Shoots were fixed to horizontal rods compelling leaves to face upwards. Vegetative growth was controlled by pruning, in order to not-exceed an optimal leaf area to grape mass ratio (ca. 12 leaves per plant). The experiment was carried out in glass-houses [23] at the University of Navarra (Pamplona, Spain, 4248'14" N, 139'54" W) from April to September 2011. Throughout all the experiment, growth conditions in the glass-houses were $25 / 15^{\circ} \mathrm{C}, 50 / 90 \%$ relative humidity $(\mathrm{RH})$ (day/night) and natural light. Glass-house walls and structure filtered up to $99.9 \%$ of UV-B, $35 \%$ of UV-A and $15 \%$ of the photosynthetically active radiation (PAR) coming from the sun. A supplemental system of high-pressure sodium lamps (SON-T Agro Philips, Eindhoven, 
Netherlands) was triggered when PAR dropped below a photon flux density of $1000 \mu \mathrm{mol} \mathrm{m} \mathrm{m}^{-2}$ (14h photoperiod) [23].

\subsection{Experimental design}

When fruit-set was complete for all plants, three levels of biologically effective UV-B $(0,5.98$ and $9.66 \mathrm{~kJ} \mathrm{~m}^{-2} \mathrm{~d}^{-1}$ ), calculated using the generalized plant action spectrum of Caldwell [24] as formulated by Green et al. [25], and two water availabilities (well watered and water deficit) were applied in a factorial design (12 plants per treatment) until maturity.

UV-B was applied by means of narrow band lamps TL100W/01 (311-313 spectrum peaking; Philips, Netherlands) hanging above the canopy. Spectral scans were performed with a double monochromator spectroradiometer (model SR9910, Macam Photometrics Ltd., Livingstone, Scotland) (Fig. S1). UV-A radiation emitted by the lamps accounted for less than $1 \%$ of the solar UV-A irradiance $\left(\mathrm{W} \mathrm{m}^{-2}\right)$ reaching the plants during the irradiation period. In the treatment of 0 $\mathrm{kJ} \mathrm{m}^{-2} \mathrm{~d}^{-1}$, lamps on top were unlit. The UV-B doses of 5.98 and $9.66 \mathrm{~kJ} \mathrm{~m}^{-2} \mathrm{~d}^{-1}$ were applied using the same fluence rate $\left(0.55 \mathrm{~W} \mathrm{~m}^{-2}\right)$, but during different exposure times: $3 \mathrm{~h}$ for the dose of $5.98 \mathrm{~kJ} \mathrm{~m}^{-2} \mathrm{~d}^{-1}$ and $3 \mathrm{~h}$ and $51 \mathrm{~min}$ for the dose of $9.66 \mathrm{~kJ} \mathrm{~m}^{-2} \mathrm{~d}^{-1}$. The applied biologically effective dose of $5.98 \mathrm{~kJ} \mathrm{~m}^{-2} \mathrm{~d}^{-1}$ corresponded to $86 \%$ of the maximum daily dose at the study site, whereas $9.66 \mathrm{~kJ} \mathrm{~m}^{-2} \mathrm{~d}^{-1}$ is only reached in viticulture suitable sites of the southern hemisphere, such as Argentina, South Africa or Australia .

Soil water sensors (Watermark ${ }^{\mathrm{TM}}$ soil moisture sensors, Irrometer, USA), placed in every pot, were used to control irrigation. Well watered plants were maintained at around $80 \%$ of substrate field capacity. Water deficit plants received only $50 \%$ of the water received by well-watered plants. Irrigation was performed with the nutritive solution described by Ollat et al. [19]. Nutrient solution concentrations were adjusted to provide the same amount of nutrients to each treatment batch.

Water status, gas exchange, chlorophyll fluorescence and MEUVAC were measured 7, 30 and 60 days after the beginning of the treatments. Maximum potential efficiency of photosystem II (Fv/Fm) was measured on days 1 to $7,15,30$ and 60 after the beginning of the treatments. Plant growth, leaf photosynthetic pigments, antioxidant enzymes and lipid peroxidation were 
measured after 60 days of treatment. Given the importance of comparing leaves of the same physiological age in UV studies, young fully expanded leaves of the same age (around four week old) were chosen. On day 7 , these leaves had been fully developed before the beginning of the treatments, under the glass-house conditions described previously. On day 30 and 60, young fully expanded leaves developed during the treatments were chosen, as far as possible.

\subsection{Plant growth parameters and phenological development}

At maturity, leaf area was measured immediately after harvest with a leaf area meter (LI300 model; Li-Cor, Lincoln, USA). Leaf dry matter (DM) was determined after drying at $80^{\circ} \mathrm{C}$ for 2 days. Distance between shoot nodes was also determined. Three events (fruit-set, onset of veraison and maturity) were selected for the study of phenological development, determined as the elapsed time (days) between fruit-set to the onset of veraison, between the onset of veraison to maturity and between fruit-set and maturity.

\subsection{Leaf relative water content (RWC)}

Relative water content (RWC) was estimated by a modification of the method of Wheatherley [26], using leaf discs of $1 \mathrm{~cm}^{2}$, and calculated as RWC $=100 \times(\mathrm{FW}-\mathrm{DW}) /(\mathrm{TW}$ DW), where FW, DW and TW denote fresh, dry and turgid weight, respectively. TW was calculated after fully hydrating fresh leaf discs in darkness at $4^{\circ} \mathrm{C}$ for $24 \mathrm{~h}$. DW was determined after drying at $80^{\circ} \mathrm{C}$ for 2 days in an oven.

\subsection{Gas exchange and chlorophyll fluorescence}

Gas exchange measurements were conducted using a portable photosynthesis system (GFS3000 , Walz, Germany) with a $3 \mathrm{~cm}^{2}$ cuvette. Dark respiration $\left(R_{\mathrm{D}}\right)$ measurements were performed $2 \mathrm{~h}$ before the beginning of the light period. Environmental conditions in the measurement chamber were: ambient $\mathrm{CO}_{2}$ concentration $=375 \mathrm{ppm}$, air temperature $=25^{\circ} \mathrm{C}$ and $\mathrm{RH}=50 \%$. Gas exchange characteristics in illuminated leaves were measured at mid-morning under the same environmental conditions in the cuvette, and with a photosynthetically active photon flux density (PPFD) of $1200 \mu \mathrm{mol}$ photons $\mathrm{m}^{-2} \mathrm{~s}^{-1}$. Net photosynthesis $\left(A_{\text {net }}\right)$, stomatal conductance $\left(\mathrm{g}_{\mathrm{s}}\right)$, sub-stomatal $\mathrm{CO}_{2}$ concentration $(\mathrm{Ci})$ and $R_{\mathrm{D}}$ were calculated according to von Caemmerer and Farquhar [27]. Chl fluorescence was measured immediately after the gas 
exchange measurements (in the dark and in the light), with a fluorescence module (PAMfluorometer 3055-FL, Walz, Germany) attached to the photosynthesis equipment. The experimental protocol for analysis of Chl fluorescence quenching was performed according to Martínez-Lüscher, et al. [17]. Parameters monitored were maximum potential PSIl efficiency $(\mathrm{Fv} / \mathrm{Fm}=(\mathrm{Fm}-\mathrm{Fo}) / \mathrm{Fm})$, actual PSII efficiency $\left(\Phi_{\mathrm{PSII}}=\left(\mathrm{Fm} \mathrm{m}^{\prime}-\mathrm{Fs}\right) / \mathrm{Fm} \mathrm{m}^{\prime}\right)$, photochemical quenching $\left(\mathrm{qP}=\left(\mathrm{Fm} \mathrm{m}^{\prime}-\mathrm{Fs}\right) /\left(\mathrm{Fm}^{\prime}-\mathrm{Fo}^{\prime}\right)\right)$ and non-photochemical quenching $\left(\mathrm{NPQ}=\left(\mathrm{Fm} / \mathrm{Fm} \mathrm{m}^{\prime}\right)-1\right)$. The electron transport rate was calculated as: $E T R=\Phi_{P S I I} \times$ PPFD $\times 0.5 \times 0.84$, according to Krall and Edwards [28], where 0.5 was used as the fraction of energy distributed between the two photosystems [29] and 0.84 is the fractional leaf absorptance [30]. Multiplying $0.84 \times 0.5$ gives a value of 0.42 , a value very similar to the $\alpha$ term reported for grapevine cv. Tempranillo [31]. Photorespiration was estimated as: $R_{\mathrm{L}}=1 / 12\left(\mathrm{ETR}-4 \times\left(A_{\text {net }}+R_{\mathrm{D}}\right)\right)$, according to Valentini, et al. [32].

\subsection{Sampling for biochemical assays}

The same leaves used for photosynthesis and $\mathrm{Chl}$ fluorescence measurements were used for the biochemical analysis. Two leaf disks of $1 \mathrm{~cm}^{2}$ were harvested immediately after gas exchange and $\mathrm{Chl}$ fluorescence measurements, cut with a calibrated cork borer, wrapped in aluminum foil, immediately plunged into liquid $\mathrm{N}_{2}$ and stored at $-80^{\circ} \mathrm{C}$ until photosynthetic pigments and MEUVAC analyses. Then, the leaf was detached and frozen in liquid $\mathrm{N}_{2}$ for lipid peroxidation (thiobarbituric acid reacting substances, TBARS), antioxidant enzyme activities and protein determinations.

\subsection{Methanol extractable UV-B absorbing compounds (MEUVAC) and photosynthetic pigments}

Methanol extractable UV-B absorbing compounds were determined according to Dai et al. [33]. Frozen leaf disks were extracted with $10 \mathrm{~mL}$ of methanol:water:7M $\mathrm{HCl}(70: 29: 1$ by volume) at $85^{\circ} \mathrm{C}$ in the dark for $15 \mathrm{~min}$. The extracts were centrifuged at $2,000 \mathrm{~g}$ for $15 \mathrm{~min}$, and the absorbance spectrum was measured in a spectrophotometer UV/Vis (UVMini 1240, Shimadzu, Kyoto, Japan). The amount of MEUVAC was expressed in arbitrary units as the area under the absorbance curve in the UV-B interval $\left(\mathrm{AUC}_{280-315}\right)$, calculated per unit of leaf area. 
Leaf photosynthetic pigments were determined according to Larbi et al. [34]. Pigments were extracted with acetone in the presence of sodium ascorbate, filtered $(0.45-\mu \mathrm{m})$ and quantified by HPLC. Two eluents were used: mobile phase A (acetonitrile:methanol, 7:1, v/v) was pumped for $3.5 \mathrm{~min}$, and then mobile phase B (acetonitrile:methanol:water:ethyl acetate, 7:0.96:0.04:8 by volume) was pumped for $4.5 \mathrm{~min}$. Modified triethylamine ( $0.7 \%$ by volume) was added to both solvents to improve pigment stability. De-epoxidation state of the xanthophyll cycle was calculated as: $D E S=(A+Z) /(V+A+Z)$, where $V, A$ and $Z$ were antheraxanthin, violaxanthin and zeaxanthin concentrations, respectively.

\subsection{Determination of total soluble protein and antioxidant enzymes}

Frozen leaf tissue $(1 \mathrm{~g})$ was homogenized with $10 \mathrm{~mL}$ of $0.1 \mathrm{M}$ potassium phosphate buffer $(\mathrm{pH}$ 7.0), containing $0.1 \mathrm{mM}$ EDTA-Na, $0.5 \mathrm{mM}$ ascorbate and 1\% PVPP (polyvinyl polypyrrolidone) in an ice bath. The homogenate was filtered and centrifuged at $28,710 \mathrm{~g}$ and $4^{\circ} \mathrm{C}$ for $10 \mathrm{~min}$. The supernatant was used for determinations of protein content and antioxidant enzyme activity. Total soluble protein concentration was determined as described by Bradford [35] using bovine serum albumin as standard. Superoxide dismutase (SOD, EC 1.15.1.1) was determined by the nitroblue tetrazolium (NBT) method [36] with some modifications. Guaiacol peroxidase (GPX, EC 1.11.1.7) assay was performed using the method described by Pütter [37]. Catalase (CAT, EC 1.11.1.6) activity was assayed by measuring the rate of $\mathrm{H}_{2} \mathrm{O}_{2}$ disappearance at 260 $\mathrm{nm}$ as described by Aebi [38] with some modifications. Ascorbate peroxidase (APX, CE 1.11.1.11) activity was determined as described by Nakano and Asada [39] with some modifications. See Martínez-Lüscher et al. [17] for more details on enzyme activity determination and methods modification.

\subsection{Determination of lipid peroxidation}

Lipid peroxidation was estimated by measuring the concentration of thiobarbituric acid reacting substances (TBARS), as described by Dhindsa et al. [36], in leaf samples taken 60 days after the beginning of the experiments. Frozen leaf tissue $(0.5 \mathrm{~g})$ was homogenized with $10 \mathrm{~mL}$ trichloroacetic acid (TCA) $0.1 \%(\mathrm{w} / \mathrm{v})$ in an ice bath, filtered and centrifuged at $28,710 \mathrm{~g}$ and $4^{\circ} \mathrm{C}$ for $10 \mathrm{~min}$. Two $\mathrm{mL}$ of extract were mixed with an equal volume of either (i) $20 \%$ (w/v) TCA solution or (ii) $20 \%$ TCA solution containing $0.5 \%(w / v)$ TBA. The mixtures were incubated into a 
hot bath $\left(95^{\circ} \mathrm{C}\right)$ for $30 \mathrm{~min}$ and centrifuged at $10,000 \mathrm{~g}$ and $4^{\circ} \mathrm{C}$ for $10 \mathrm{~min}$. The absorbance of the supernatant was read at $532 \mathrm{~nm}$ and $600 \mathrm{~nm}$. TBARS concentration was calculated as: $\left[\left(A_{532} \times 1000\right)-\left(A_{600} \times 1000\right)\right] / 155$ being 155 the extinction coefficient in $\mathrm{mM}^{-1} \mathrm{~cm}^{-1}[40]$.

\subsection{Statistical analyses}

Statistical analysis was performed using XLstat-Pro (Addisoft). The data were subjected to a three-factor analysis (ANOVA $3 \times 3 \times 2$ ) to partition the variance into the main effects (stage, UV-B and water deficit) and the interaction among them. In case of significant interaction among factors, treatments were compared using the least significant difference (LSD) post-hoc test $(p<0.05)$.

\section{RESULTS}

\subsection{Phenological development and plant growth parameters}

UV-B radiation applied alone significantly delayed (up to 11 days in the case of the dose of 5.98 $\mathrm{kJ} \mathrm{m}^{-2} \mathrm{~d}^{-1}$ ) the phenological development of grapevine plants compared with those non-exposed, particularly after veraison (Table 1). Water deficit significantly shortened (up to three days) the period between fruit-set and the onset of veraison, but clearly delayed maturity, especially in the plants exposed to $9.66 \mathrm{~kJ} \mathrm{~m}^{-2} \mathrm{~d}^{-1}$ of UV-B (23 days). UV-B radiation significantly effected reductions in shoot growth, measured as internodal length, irrespective of water regime applied, whereas water deficit caused reductions in leaf area, leaf dry matter and shoot internodal length (Table 1).

\subsection{Leaf water status}

Leaf stomatal conductance decreased as substrate water potential decreased, regardless of the UV-B dose (Fig. 1A). Both UV-B and water deficit led to small reductions in the relative water content of plants (between 2-5\%, 1B). However, the effect of UV-B was more evident in well irrigated plants compared with those subjected to water deficit on day 7 and 60 after the beginning of the treatments (Fig. 1B).

\subsection{Gas exchange and chlorophyll fluorescence}


The treatment with $9.66 \mathrm{~kJ} \mathrm{~m}^{-2} \mathrm{~d}^{-1}$ of UV-B transiently (day 7) caused reductions in $A_{\text {net }}$ and $\mathrm{g}_{\mathrm{s}}$ under well-watered and water deficit conditions (differences not significant in the last situation), and increased $R_{\mathrm{L}}$ and $\mathrm{R}_{\mathrm{D}}$ only in the plants subjected to water deficit (Fig. 2). $\Phi_{\mathrm{PSII}}$ and $\mathrm{qP}$ were lower after 7 and 30 days of exposure to $9.66 \mathrm{~kJ} \mathrm{~m}^{-2} \mathrm{~d}^{-1}$ of UV-B, compared with non-exposed plants, only under well-watered conditions (Fig. 3). Water deficit, in general, significantly effected reductions in $A_{\text {net }}, \mathrm{g}_{\mathrm{s}}, \mathrm{E}, \mathrm{Ci}, \Phi_{\mathrm{PSI}}$ and $\mathrm{qP}$ values throughout the experiment, with respect to well watered conditions (Fig. 2 and 3). By contrast, deficit irrigation caused increase in $R_{\mathrm{L}}$ and the ratio $\mathrm{ETR} / A_{\mathrm{net}}+R_{\mathrm{D}}+R_{\mathrm{L}}$, regardless of the dose of UV-B applied. NPQ was not significantly modified by UV-B or water deficit (Fig. 3). UV-B transiently effected decrease in Fv/Fm during the first eight days of exposure, recovering afterwards to control values (Fig. 4). There was no significant interaction between UV-B dose, water availability and developmental stage for most of the photosynthetic parameters measured, except for $R_{D}$ (Fig. 2).

\subsection{Photosynthetic pigments and methanol extractable UV-B absorbing compounds (MEUVAC)}

Plants treated with UV-B radiation had higher concentrations of MEUVAC in leaves than those non-irradiated, after 30 and 60 days of exposure and under both water availabilities (Fig. 5). Water deficit did not affect the concentration of MEUVAC of plants irradiated with UV-B ( $P_{\text {(UV- }}$ $B \times W A=0.093$ ). Only in non-irradiated plants, the concentration of UV-B absorbing compounds under water deficit was significantly lower compared with well watered conditions on day 30 (Fig. 5).

UV-B radiation applied alone did not significantly modify the concentration of $\mathrm{Chl}$ and carotenoids after 60 days of treatment (Table 2). Water deficit significantly effected increase in $\mathrm{Chl}$ concentration per unit of leaf area, especially when combined with UV-B $\left(P_{(U V \times W A)}=0.05\right)$. When UV-B was applied in combination with water deficit, it caused increase in neoxanthin and decrease in zeaxanthin concentrations and the de-epoxidation stage of xanthophyll cycle, with respect to plants non-irradiated. Significant interactions between UV-B and water availability were observed for $\beta$-carotene, lutein, neoxanthin, zeaxanthin and DES.

\subsection{Total soluble proteins, antioxidant enzymes and lipid peroxidation}


UV-B radiation did not significantly modify the concentration of leaf soluble proteins, whereas water deficit caused increase in TSP after 60 days of exposure (Table 3). Neither UVB nor water deficit significantly modified the levels of TBARS (Table 3). Plants irradiated with UV-B had higher SOD activity, but similar CAT, GPX and APX activities, compared with those non-irradiated, regardless of water availability (Table 3). Water deficit did not modify, in general, the activity of antioxidant enzymes, and it only significantly effected decrease in CAT activity in plants exposed to $5.98 \mathrm{~kJ} \mathrm{~m}^{-2} \mathrm{~d}^{-1}$. There were no significant interactions between UV-B and water availability for any of these biochemical parameters (Table 3).

\section{DISCUSSION}

\subsection{Grapevine acclimation to UV-B}

The main effects of UV-B radiation reducing $A_{\text {net }}$ were observed after 7 days of exposure on well-watered plants (Fig. 2). Contrarily to previous studies on grapevine [6, 17], such decrease was not accompanied by a reduction in the concentration of sub-stomatal $\mathrm{CO}_{2}$ concentration. Therefore, reduction in $\mathrm{CO}_{2}$ availability did not seem to be the main factor limiting $\mathrm{CO}_{2}$ fixation in the plants exposed to UV-B. The slight down-regulation of PSII activity ( $\left.\Phi_{P S I I}\right)$ observed on day 7 , through a decrease in the proportion of the reaction centers that remained open (qP), may have contributed to the impaired $A_{\text {net }}$ of UV-B exposed plants (Fig. 3). Along with the decrease observed in $A_{\text {net }}$, UV-B transiently induced a significant decrease in the maximum potential efficiency of PSII (Fv/Fm) during the first seven days of exposure (Fig. 4), thus indicating that grapevine leaves experienced a certain degree of stress during this period, recovering afterwards in absence of permanent PSII photoinhibition. The Fv/Fm is also a direct measurement of the PSII efficiency that excludes the indirect effect of UV-B reducing stomatal aperture and thereby limiting gas exchange [6].

One of the most important molecular events underlying UV-B protection and acclimation in plants, including grapevine, is the activation of the antioxidant system, which includes de accumulation of non-enzymatic and enzymatic antioxidants $[5,17]$. Among the non-enzymatic antioxidants, the accumulation of phenolic compounds, mainly dihydroxy flavonoids [41], in the vacuoles of epidermal cells reduces the penetration of UV wavelengths deeper into leaves [6]. These compounds are also accumulated in the chloroplasts and vacuoles of mesophyll cells, 
where they may have a functional role in photoprotection, as $\mathrm{H}_{2} \mathrm{O}_{2}$ and singlet oxygen scavengers [7]. In the present study, the levels of MEUVAC in the plants exposed to UV-B for 7 days were not significantly higher than the levels of non-exposed plants (Fig. 5). These results suggest that during the first days of UV-B exposure, grapevine leaves, which had been fully developed without UV-B, were not able to accumulate enough amounts of phenolic compounds to protect the photosynthetic apparatus from UV-B radiation, thus showing a transient impairment of the photosynthetic performance (Fig. 2 to 4). Comont, et al. [14] reported that whereas this protective response builds up gradually in the field, plants grown in zero UV-B glasshouse conditions (as was this case) do not build such protection and/or the rapid capacity to respond to UV-B. Nevertheless, after 30 and 60 days of exposure to UV-B, grapevine leaves doubled their concentration of MEUVAC. The increased activity of the antioxidant system also includes up-regulation of antioxidant enzymes such as SOD, CAT and peroxidases [5]. Elicitation of antioxidant enzymes response may be mediated by reactive oxygen species and/or the UV-B specific photoreceptor signaling pathway [5]. In the present study, a significant increase in SOD activity was observed after 60 days of UV-B exposure (Table 3), thus leading to an increased capacity to scavenge oxygen free radical. Such increase in SOD, together with the accumulation of MEUVAC, provided not only an effective protection of the photosynthetic apparatus, but also protected the leaves against a potential oxidative damage induced by UV-B, as suggests the low levels of TBARS (Table 3). All of these changes are indicative of UV-B acclimation occurring following long-term exposures [17].

Regarding the effect of UV-B radiation on plant water status, most of the studies on the response of plants to UV-B show no remarkable changes in leaf RWC [8,9]. In other cases, UV-B has been reported to improve leaf water status, through production of osmolytes, accumulation of dehydrins or increases in cuticle thickness [1]. By contrast, in the present study, leaf RWC of UV-B treated plants was significantly lower (day 7 and 60) than that of plants nonexposed to UV-B (Fig. 1B), which may suggest a decrease in cell turgidity. However, such decrease in RWC cannot be explained by a higher loss of water through transpiration in UV-B exposed plants (Fig. 2). The relationship between UV-B and changes in plant cell turgidity is not clear and, our results do not allow us to give a conclusive explanation. The results agree with 
those of Yang and Yao [42] and Ziska, et al. [43], who observed decreases in leaf water status induced by UV-B in different plant species.

Effects of water deficit and its interaction with UV-B on the photosynthetic performance of grapevine

A significant decrease in $A_{\text {net }}$ was observed after 7,30 and 60 days of water deficit, regardless of the UV-B dose applied (Fig. 2). Stomatal closure seemed to be the main limitation to photosynthesis, as deduced from the impaired $\mathrm{g}_{\mathrm{s}}, \mathrm{E}$ and $\mathrm{Ci}$ values. Unlike that observed for UVB, the decrease of $\Phi_{\text {PSII }}$ induced by water deficit was smaller than that of $A_{\text {net }}$ (Fig. 2 and 3), thus reflecting an unbalance between photochemistry and $\mathrm{CO}_{2}$ fixation, which may lead to an excess of electrons generated in the photosynthetic electron transport chain. However, plants compensated for the decrease in photosynthesis maintaining $R_{\mathrm{D}}$ and significantly increasing $R_{\mathrm{L}}$ under water deficit conditions $\left(P_{(W A)}<0.0001\right)$ (Fig. 2). $R_{\mathrm{L}}$ and $R_{\mathrm{D}}$ are important mechanisms of photoprotection on grapevine, particularly under conditions of low $A_{\text {net }}$, as it occurs under water stress [44]. Therefore, the ratio of electrons generated to electrons consumed (ETR/A $\left.A_{\text {net }}+R_{\mathrm{D}}+R_{\mathrm{L}}\right)$ only increased from ca. 5 to 6-7 (Fig. 3). The results suggest that, although under water deficit alternative sink for the excess of electrons exists (such as the Mehler reaction), the risk of water stress-mediated oxidative damage was low. In fact, the concentration of proteins and Chl, main targets of ROS, did not decreased after 60 days of exposure to water deficit, and the levels of TBARS and the antioxidant enzyme activities (SOD, GPX, CAT and APX) were not increased under water-stress. Similarly, Doupis, et al. [16] observed that the activity of antioxidant enzymes in grapevine leaves did not significantly increase under water-stress. More recently, Król, et al. [45] have reported that the antioxidant activity of grapevine leaves can even decrease under long-term drought stress, as happened with CAT activity in the present study (Table 3). Such decrease in CAT activity, may involve a decreased capacity to scavenge oxygen peroxide under water deficit conditions. Nevertheless, the activity of other peroxidases (APX and GPX) seemed to be high enough to compensate such decrease in CAT, as suggests the lower values of lipid peroxidation.

Regarding the combined effect of UV-B and water deficit, the results indicate that UV-B radiation significantly affected leaf water status $(\mathrm{RWC})$ and photosynthetic activity $\left(A_{\text {net, }}, \Phi_{\mathrm{PSII}}\right.$ 
and Fv/Fm, during the first days of exposure), primarily when water availability was high, and these effects were less evident under water deficit conditions, when plant water content and photosynthetic performance was already reduced (Fig. 1 to 4 ). In addition, the combination of UV-B and deficit irrigation did not cause pronounced additive effects, with respect to the exposure to UV-B alone, on the activity of antioxidant enzymes and the accumulation of UV-B protecting pigments, two major acclimation responses of plants to UV-B radiation (Table 3 and Fig. 5). The results suggest that the adaptive response of grapevine to UV-B radiation was not modified by water deficit, and agree with previous studies, in which few interactive effects of UV-B radiation and water availability on water status, photosynthetic capacity and enzymatic antioxidant system of different plant species were observed [10-12]. There was only one key functional trait, $R_{\mathrm{D}}$, which exhibited relatively strong synergistic effect from the combined application of UV-B and water deficit on day 7 . The increase in $R_{\mathrm{D}}$, only observed in the plants exposed to UV-B and deficit irrigation, coincided with the beginning of the period of greater synthesis of UV-B protecting compounds (between day 7 and 30, Fig. 5). An increase in cell respiration has been related to the greater need for energy to protect against UV-B and for the repair of UV-B damage [46]. In addition, $R_{\mathrm{L}}$ increased especially in those plants grown under UV-B and water deficit (not significant interaction in this case) (Fig. 2), in which the decrease in the rates of carbon fixation with respect to $\Phi_{\text {PSII }}$ was more evident. The results suggest that when UV-B and water deficit were applied simultaneously, $R_{\mathrm{L}}$ and $R_{\mathrm{D}}$ were the two major photoprotective processes, whereas thermal energy dissipation was not involved in the adaptation of grapevine leaves to the combination of these factors, as indicated by the absence of changes in NPQ and DES (Fig. 3 and Table 2).

\subsection{Phenological response of grapevine to UV-B and water deficit}

One of the less studied aspects of the response of plants to the combination of UV-B and drought is their role as regulators of plant phenology and reproductive success [14]. In the present study, plants grown under a single environmental factor, UV-B radiation or water deficit, took up to 11 and 13 days longer, respectively, to reach grape berry ripeness (21-23 ${ }^{\circ}$ Brix) (Table 1). A delay of plant developmental stages (flowering and ripening) induced by UV-B has been reported for other species such as $A$. thaliana and wheat [14, 47]. Schultz [48] also reported that grapevine phenology may be affected by UV-B radiation. With respect to the effect 
of water deficit, moderate drought, in general, promotes sugar accumulation, thus accelerating grape ripening in the field $[49,50]$. Nevertheless, the effect varies depending on the timing and intensity of water stress imposition [49] and a delay in fruit maturity has been observed after pre-veraison irrigation cutoff in Cabernet Sauvignon [51]. In the present work, the onset of veraison was triggered earlier in berries under water deficit conditions, compared to well watered plants. The results agree with Castellarin, et al. [50], who observed that water deficit hastened the onset of ripening (veraison), which was associated to the accelerated accumulation of anthocyanins and anthocyanin-related gene expression. Under water deficit, an earlier increase in grape berry abscisic acid (ABA) concentration has been reported [22]. Besides its role as a stress-related signal, $\mathrm{ABA}$ has been pinpointed as the signal triggering berry ripening, since a strong increase in berry ABA content is recorded at the end of the colour turning period and during the initial stages of ripening [52]. ABA up-regulates genes associated with the ripening process, such as those involved in anthocyanin biosynthesis [53] and acts through the over- or under-expression of, mostly, the same proteins which are involved in the ripening process, in the same direction as observed during ripening [54]. In the present study, water deficit may have induced an earlier increase in the levels of ABA in the berries, thus triggering the onset of ripening before than in well-irrigated plants. Even though they started the ripening process sooner, sugar accumulation process was clearly slower in plants under water deficit, thus delaying maturity. Since berry growth and ripening greatly depend on the import of photoassimilates, the strong reduction in leaf area and photosynthetic activity observed in the plants subjected to water deficit, probably may explain the slow-down in ripening.

Interestingly, the water deficit induced delay in plant development was enhanced by UV-B radiation, and ripeness was delayed up to 28 days, when UV-B and water deficit were combined, with respect to the non-irradiated well-watered plants (Table 1). This delay was mainly associated with a slow-down of the stage III of berry growth comprised between the onset of veraison to maturity. Similarly, Comont et al. [14] reported that UV-B and drought acting simultaneously caused a delay in phenology of $A$. thaliana, compared with drought alone. In the present study, the treatment with $9.66 \mathrm{~kJ} \mathrm{~m}^{-2} \mathrm{~d}^{-1}$ of UV-B slightly caused reduction in $A_{\text {net }}$ in plants grown under water deficit conditions on day 7 and 30 (stages of fruit-set and veraison, respectively). Such additive effect of UV-B, although not statistically significant, represented an 
additional decrease in $A_{\text {net }}$ per unit of leaf area of between $10 \%$ and $23 \%$ (day 7 and 30 , respectively), with respect to the photosynthetic rates of non-irradiated water deficit plants. Taken together with the decrease in total leaf area (19\%, not significant differences), this may have effected reductions in the total amount of carbon fixed per plant, and consequently allocated to grape ripening. However, the decreases in $A_{\text {net }}$ and leaf area may not be enough to explain such phenological delay. Additionally, the effect of UV-B and water deficit increasing respiratory and photorespiratory activities should be also considered. Plants use up to $50 \%$ of recently formed $\mathrm{C}$ in respiration processes, which means that an important fraction of photoassimilates could have been wasted through $R_{\mathrm{L}}$ and $R_{\mathrm{D}}$, thus contributing to an impaired carbon balance. Finally, the secondary metabolism activation cost, associated to the use of photoassimilates to produce phenolics and other UV-B screening compounds, cannot be ruled out in order to explain the delayed phenological development in the combined treatment.

\section{CONCLUSIONS}

The results suggest that under environmental controlled conditions, water deficit had larger effects on grapevine growth and photosynthetic activity than UV-B, which only exhibited a transient detrimental effect on the photosynthesis of plants. Little interaction effects between UV-B and water deficit were detected on photosynthesis performance and UV-B radiation did not strongly aggravate the impact of deficit irrigation on the photosynthetic activity of grapevine. In general, the acclimation process of grapevine leaves to a long-term exposure to UV-B, through the accumulation of UV-B absorbing compounds, was not altered by water deficit. However, the combined exposure to UV-B and water deficit led to additive effects on plant phenological development, slowing-down grape ripening, which was associated with an impaired carbon balance under such conditions.

\section{Acknowledgements}

This work was supported by Fundación Universitaria de Navarra, Navarra-Aquitaine Cooperation Programme (Gobierno de Navarra and Conseil Régional d'Aquitaine), Ministerio de Ciencia e Innovación of Spain (MCINN BFU2011-26989), European Union (FP7-KBBE-2012-6- 
singlestage), Asociación de Amigos de la Universidad de Navarra (grant to J. M-L), UV4growth COST Action FA0906 and Gobierno de Aragón (A03 research group). Special thanks to A. Urdiain, M. Oyarzun and C. Ortega for their technical assistance.

\section{REFERENCES}

[1] H. Bandurska, J. Niedziela, T. Chadzinikolau, Separate and combined responses to water deficit and UV-B radiation, Plant Sci. 213 (2013) 98-105.

[2] K.E. Trenberth, J.T. Fasullo, Global warming due to increasing absorbed solar radiation, Geophys. Res. Lett. 36 (2009) 1-5.

[3] F. Giorgi, P. Lionello, Climate change projections for the Mediterranean region, Global Planet Change 63 (2008) 90-104.

[4] V.G. Kakani, K.R. Reddy, D. Zhao, K. Sailaja, Field crop responses to ultraviolet-B radiation: a review, Agric. For. Meteorol. 120 (2003) 191-218.

[5] E. Hideg, M.A. Jansen, A. Strid, UV-B exposure, ROS, and stress: inseparable companions or loosely linked associates?, Trends Plant Sci. 18 (2013) 107-115.

[6] F.J. Berli, R. Alonso, R. Bressan-Smith, R. Bottini, UV-B impairs growth and gas exchange in grapevines grown in high altitude, Physiol. Plant 149 (2013) 127-140.

[7] G. Agati, C. Brunetti, M. Di Ferdinando, F. Ferrini, S. Pollastri, M. Tattini, Functional roles of flavonoids in photoprotection: New evidence, lessons from the past, Plant Physiol. Biochem. 72 (2013) 35-45.

[8] V. Alexieva, I. Sergiev, S. Mapelli, E. Karanov, The effect of drought and ultraviolet radiation on growth and stress markers in pea and wheat, Plant Cell Environ. 24 (2001) 1337-1344.

[9] M. Poulson, M. Boeger, R. Donahue, Response of photosynthesis to high light and drought for Arabidopsis thaliana grown under a UV-B enhanced light regime, Photosynth. Res. 90 (2006) 79-90.

[10] V. Kovács, O.K. Gondor, G. Szalai, I. Majláth, T. Janda, M. Pál, UV-B radiation modifies the acclimation processes to drought or cadmium in wheat, Environ. Exp. Bot. 100 (2014) 122-131. 
[11] J.H. Sullivan, A.H. Teramura, Field study of the interaction between solar ultraviolet-B radiation and drought on photosynthesis and growth in soybean, Plant Physiol. 92 (1990) 141146.

[12] B. Duan, F. Ran, X. Zhang, Y. Zhang, H. Korpelainen, C. Li, Long-term acclimation of mesophyll conductance, carbon isotope discrimination and growth in two contrasting Picea asperata populations exposed to drought and enhanced UV-B radiation for three years, Agric. For. Meteorol. 151 (2011) 116-126.

[13] M. Bernal, L. Llorens, J. Badosa, D. Verdaguer, Interactive effects of UV radiation and water availability on seedlings of six woody Mediterranean species, Physiol. Plant 147 (2013) 234-247.

[14] D. Comont, A. Winters, D. Gwynn-Jones, Acclimation and interaction between drought and elevated UV-B in A. thaliana: Differences in response over treatment, recovery and reproduction, Ecol. Evol. 2 (2012) 2695-2709.

[15] S. Turtola, M. Rousi, J. Pusenius, K. Yamaji, S. Heiska, V. Tirkkonen, B. Meier, R. Julkunen-Tiitto, Genotypic variation in drought response of willows grown under ambient and enhanced UV-B radiation, Environ. Exp. Bot. 56 (2006) 80-86.

[16] G. Doupis, K. Chartzoulakis, A. Beis, A. Patakas, Allometric and biochemical responses of grapevines subjected to drought and enhanced ultraviolet-B radiation, Aust. J. Grape Wine Res. 17 (2011) 36-42.

[17] J. Martínez-Lüscher, F. Morales, S. Delrot, M. Sánchez-Díaz, E. Gomés, J. Aguirreolea, I. Pascual, Short- and long-term physiological responses of grapevine leaves to UV-B radiation, Plant Sci. 213 (2013) 114-122.

[18] E. Núñez-Olivera, J. Martínez-Abaigar, R. Tomás, S. Otero, M. Arróniz-Crespo, Physiological effects of solar ultraviolet-B exclusion on two cultivars of Vitis vinifera L. from La Rioja, Spain, Am. J. Enol. Vitic. 57 (2006) 441-448.

[19] N. Ollat, L. Geny, S. J., Les boutures fructifères de vigne: validation d'un modèle d'etude du development de la physiologie de la vigne. I. Caractèristiques de l'appareil vegetative, J. Int. Sci. Vigne Vin 32 (1998) 1-8. 
[20] Z.W. Dai, C. Leon, R. Feil, J.E. Lunn, S. Delrot, E. Gomes, Metabolic profiling reveals coordinated switches in primary carbohydrate metabolism in grape berry (Vitis vinifera L.), a non-climacteric fleshy fruit, J. Exp. Bot. 64 (2013) 1345-1355.

[21] C. Salazar-Parra, J. Aguirreolea, M. Sánchez-Díaz, J.J. Irigoyen, F. Morales, Photosynthetic response of Tempranillo grapevine to climate change scenarios, Ann. Appl. Biol. 161 (2012) 277-292.

[22] M. Niculcea, J. López, M. Sánchez-Díaz, M. Carmen Antolín, Involvement of berry hormonal content in the response to pre- and post-veraison water deficit in different grapevine (Vitis vinifera L.) cultivars, Aust. J. Grape Wine Res. 20 (2014) 281-291.

[23] F. Morales, I. Pascual, M. Sánchez-Díaz, J. Aguirreolea, J.J. Irigoyen, N. Goicoechea, M.C. Antolín, M. Oyarzun, A. Urdiain, Methodological advances: using greenhouses to simulate climate change scenarios, Plant Sci. 226 (2014) 30-40.

[24] M.M. Caldwell, Solar ultraviolet radiation and the growth and development of higher plants, In: A.C., Giese, ed. Photophysiology. Volume 6. Academic Press, New York (1971) 77-131. [25] A.E.S. Green, T. Sawada, E.P. Shettle, The middle ultraviolet reaching the ground, Photochem. Photobiol. 19 (1974) 251-259.

[26] P.E. Wheatherley, Studies in the water relations of the cotton plant. I. The field measurements of water deficit in leaves, New Phytol. 49 (1950) 81-87.

[27] S. von Caemmerer, G.D. Farquhar, Some relationships between the biochemistry of photosynthesis and the gas exchange of leaves, Planta 153 (1981) 376-387.

[28] J.P. Krall, G.E. Edwards, Relationship between photosystem II activity and $\mathrm{CO}_{2}$ fixation in leaves, Physiol. Plant 86 (1992) 180-187.

[29] E. Ögren, J.R. Evans, Photosynthetic light-response curves, Planta 189 (1993) 182-190.

[30] H.R. Schultz, Leaf absorptance of visible radiation in Vitis vinifera L.: estimates of age and shade effects with a simple field method, Scientia Horticulturae 66 (1996) 93-102.

[31] A. Perez-Martin, J. Flexas, M. Ribas-Carbo, J. Bota, M. Tomas, J.M. Infante, A. DiazEspejo, Interactive effects of soil water deficit and air vapour pressure deficit on mesophyll conductance to CO2 in Vitis vinifera and Olea europaea, J. Exp. Bot. 60 (2009) 2391-2405. [32] R. Valentini, D. Epron, P. De Angelis, G. Matteucci, E. Dreyer, In situ estimation of net $\mathrm{CO}_{2}$ assimilation, photosynthetic electron flow and photorespiration in Turkey oak (Q. cerris L.) 
leaves: diurnal cycles under different levels of water supply, Plant Cell Environ. 18 (1995) 631640.

[33] Q. Dai, N.H. Furness, M.K. Upadhyaya, UV-absorbing compounds and susceptibility of weedy species to UV-B radiation, Weed Biol. Manag. 4 (2004) 95-102.

[34] A. Larbi, A. Abadía, F. Morales, J. Abadía, Fe resupply to Fe-deficient sugar beet plants leads to rapid Changes in the violaxanthin cycle and other photosynthetic characteristics without significant de novo chlorophyll synthesis, Photosynth. Res. 79 (2004) 59-69.

[35] M.M. Bradford, A rapid and sensitive method for the quantitation of microgram quantities of protein utilizing the principle of protein-dye binding, Anal. Biochem. 72 (1976) 248-254.

[36] R.S. Dhindsa, P. Plumb-Dhindsa, T.A. Thorpe, Leaf senescence: correlated with increased levels of membrane permeability and lipid peroxidation, and decreased levels of superoxide dismutase and catalase, J. Exp. Bot. 32 (1981) 93-101.

[37] J. Pütter, Peroxidases, in: H.U. Bergmeyer (Ed.), Methods of Enzymatic Analysis, Verlag Chemie-Academic Press, New York, 1974, pp. 685-690.

[38] H. Aebi, Catalase in vitro, in: P. Lester (Ed.) Methods Enzymol., Academic Press, 1984, pp. 121-126.

[39] Y. Nakano, K. Asada, Hydrogen peroxide is scavenged by ascorbate-specific peroxidase in spinach chloroplasts, Plant Cell Physiol. 22 (1981) 867-880.

[40] R.L. Heath, L. Packer, Effect of light on lipid peroxidation in chloroplasts, Biochem. Biophys. Res. Commun. 19 (1965) 716-720.

[41] J. Martínez-Lüscher, N. Torres, G. Hilbert, T. Richard, M. Sánchez-Díaz, S. Delrot, J. Aguirreolea, I. Pascual, E. Gomès, Ultraviolet-B radiation modifies the quantitative and qualitative profile of flavonoids and amino acids in grape berries, Phytochemistry 102 (2014) 106-114.

[42] Y.Q. Yang, Y. Yao, Photosynthetic responses to solar UV-A and UV-B radiation in low-and high-altitude populations of Hippophae rhamnoides, Photosynthetica 46 (2008) 307-311.

[43] H. Ziska, A.H. Teramura, J.H. Sullivan, Physiological sensitivity of plants along and elevational gradent to UV-B radiation Am. J. Bot. 79 (1992) 863-871. 
[44] J. Flexas, J. Bota, J.M. Escalona, B. Sampol, H. Medrano, Effects of drought on photosynthesis in grapevines under field conditions: an evaluation of stomatal and mesophyll limitations, Funct. Plant Biol. 29 (2002) 461-471.

[45] A. Król, R. Amarowicz, S. Weidner, Changes in the composition of phenolic compounds and antioxidant properties of grapevine roots and leaves (Vitis vinifera L.) under continuous of long-term drought stress, Acta Physiol. Plant. 36 (2014) 1491-1499.

[46] M. Germ, T. Simčič, A. Gaberščik, B. Breznik, M. Hrastel, UV-B treated algae exhibiting different responses as a food source for Daphnia magna, J. Plankton Res. 26 (2004) 12191228.

[47] L. Yuan, Y. Ming, W. Xunling, Effects of enhanced ultraviolet-B radiation on crop structure, growth and yield components of spring wheat under field conditions, Field Crops Res. 57 (1998) 253-263.

[48] H. Schultz, Climate change and viticulture: a European perspective on climatology, carbon dioxide and UV-B effects, Aust. J. Grape Wine Res. 6 (2000) 2-12.

[49] M.M. Chaves, O. Zarrouk, R. Francisco, J.M. Costa, T. Santos, A.P. Regalado, M.L. Rodrigues, C.M. Lopes, Grapevine under deficit irrigation: hints from physiological and molecular data, Ann. Bot. (Lond.) 105 (2010) 661-676.

[50] S.D. Castellarin, M.A. Matthews, G. Di Gaspero, G.A. Gambetta, Water deficits accelerate ripening and induce changes in gene expression regulating flavonoid biosynthesis in grape berries, Planta 227 (2007) 101-112.

[51] M.J. Sipiora, M.-J.G. Granda, Effects of pre-veraison irrigation cutoff and skin contact time on the composition, color, and phenolic content of young Cabernet Sauvignon wines in Spain, Am. J. Enol. Vitic. 49 (1998) 152-162.

[52] N. Kuhn, L. Guan, Z.W. Dai, B.-H. Wu, V. Lauvergeat, E. Gomès, S.-H. Li, F. Godoy, P. Arce-Johnson, S. Delrot, Berry ripening: recently heard through the grapevine, J. Exp. Bot. 65 (2014) 4543-4559.

[53] K. Koyama, K. Sadamatsu, N. Goto-Yamamoto, Abscisic acid stimulated ripening and gene expression in berry skins of the Cabernet Sauvignon grape, Funct. Integr. Genomics 10 (2010) 367-381. 
[54] M. Giribaldi, L. Gény, S. Delrot, A. Schubert, Proteomic analysis of the effects of ABA treatments on ripening Vitis vinifera berries, J. Exp. Bot. 61 (2010) 2447-2458.

\section{Figure captions}

Figure 1. Relationship between stomatal conductance $\left(g_{s}, A\right)$ and substrate water potential and relative water content (RWC, B) of plants grown under $0,5.98$ and $9.66 \mathrm{~kJ} \mathrm{~m}^{-2} \mathrm{~d}^{-1}$ of UV-B, well watered and water deficit. In Fig. $B$, columns are means $(n=9) \pm S E$. Different letters within the same parameter indicate significant differences $(p<0.05)$.

Figure 2. Net photosynthesis $\left(A_{\text {net }}\right)$, stomatal conductance $\left(g_{s}\right)$, transpiration $(E)$, sub-stomatal $\mathrm{CO}_{2}$ concentration $(\mathrm{Ci})$, photorespiration $\left(R_{\mathrm{L}}\right)$ and dark respiration $\left(R_{\mathrm{D}}\right)$ of plants grown under 0 , 5.98 and $9.66 \mathrm{~kJ} \mathrm{~m}^{-2} \mathrm{~d}^{-1}$ of UV-B, well watered (WW) and water deficit (WD), after 7, 30 and 60 days of treatment. Columns are means $(n=9) \pm$ SE. Different letters within the same parameter indicate significant differences $(\mathrm{p}<0.05)$. Main effects of UV-B $\left(P_{(U V-B)}\right)$, water availability $\left(P_{(W A)}\right)$ and interaction between UV-B, water availability and developmental stage ( $\left.P_{(U V-B \times W A x S t a g e)}\right)$.

Figure 3. Actual PSII efficiency ( $\Phi_{P S I I}$ ), non-photochemical quenching (NPQ) and photochemical quenching (qP), and ratio of electrons generated to electrons consumed in $A_{\text {net }}, R_{\mathrm{D}}$ and $R_{\mathrm{L}}$ $\left(\mathrm{ETR} / A_{\text {net }}+R_{\mathrm{D}}+R_{\mathrm{L}}\right)$ of plants grown under $0,5.98$ and $9.66 \mathrm{~kJ} \mathrm{~m}^{-2} \mathrm{~d}^{-1}$ of UV-B, well watered (WW) and water deficit (WD), after 7,30 and 60 days of treatment. Columns are means $(n=9) \pm S E$. Different letters within the same parameter indicate significant differences $(p<0.05)$. Main effects of UV-B $\left(P_{(U V-B)}\right)$, water availability $\left(P_{(W A)}\right)$ and interaction between UV-B, water availability and developmental stage $\left(P_{(U V-B \times W A x S t a g e)}\right)$.

Figure 4. Maximum potential PSII efficiency (Fv/Fm) of plants grown under $0,5.98$ and $9.66 \mathrm{~kJ}$ $\mathrm{m}^{-2} \mathrm{~d}^{-1}$ of UV-B, well watered (WW) and water deficit (WD), throughout the experiment. Points are means $(n=9) \pm$ SE. Significant differences $(p<0.05)$ between UV-B doses and water regimes within the same date are indicated as * and $\bullet$, respectively. Main effects of UV-B $\left(P_{(U V-B)}\right)$, water availability $\left(P_{(\text {WA }}\right)$ and interaction between UV-B, water availability and developmental stage $\left(P_{(U V-B x W A x \text { Stage })}\right)$. Inset is a zoom of the seven first days of treatment. 
Figure 5. Leaf methanol extractable UV-B absorbing compounds (MEUVAC) of plants grown under $0,5.98$ and $9.66 \mathrm{~kJ} \mathrm{~m}^{-2} \mathrm{~d}^{-1}$ of UV-B, well watered (WW) and water deficit (WD), after 7, 30 and 60 days of treatment. Columns are means $(n=9) \pm$ SE. Different letters within the same parameter indicate significant differences $(p<0.05)$. Main effects of UV-B $\left(P_{(U V-B)}\right)$, water availability $\left(P_{(W A)}\right)$ and interaction between UV-B, water availability and developmental stage $\left(P_{(U V-B \times W A x S t a g e)}\right)$.

Figure S1. Spectral irradiance of the UV-B lamps. 
Table 1. Phenological development and growth parameters of plants grown under $0,5.98$ and $9.66 \mathrm{~kJ} \mathrm{~m}^{-2} \mathrm{~d}^{-1}$, well watered and water deficit, at maturity. Values are means $(\mathrm{n}=12)$ and standard errors. Main effects of UV-B $\left(P_{(U V-B)}\right)$, water availability $\left(P_{(W A)}\right)$ and interaction between UV-B and water availability $\left(P_{(U V-B x W A)}\right)$.

\begin{tabular}{|c|c|c|c|c|c|c|c|c|c|}
\hline & \multicolumn{3}{|c|}{ Well Watered } & \multicolumn{3}{|c|}{ Water Deficit } & \multirow[b]{2}{*}{$P_{(U V-B)}$} & \multirow[b]{2}{*}{$P_{(W A)}$} & \multirow[b]{2}{*}{$\boldsymbol{P}_{\text {(UV'WA) }}$} \\
\hline & $0 \mathrm{~kJ} \mathrm{~m}^{-2} \mathrm{~d}^{-1}$ & $5.98 \mathrm{~kJ} \mathrm{~m}^{-2} \mathrm{~d}^{-1}$ & $9.66 \mathrm{~kJ} \mathrm{~m}^{-2} \mathrm{~d}^{-1}$ & $0 \mathrm{~kJ} \mathrm{~m}^{-2} \mathrm{~d}^{-1}$ & $5.98 \mathrm{~kJ} \mathrm{~m}^{-2} \mathrm{~d}^{-1}$ & $9.66 \mathrm{~kJ} \mathrm{~m}^{-2} \mathrm{~d}^{-1}$ & & & \\
\hline Elapsed time from fruit set to the & & & & & & & & & \\
\hline onset of veraison (days) & $41.2(1.3)$ & $41.7(0.7)$ & $42.9(0.9)$ & $40.0(0.8)$ & $39.8(0.9)$ & $40.1(1.0)$ & 0.574 & 0.012 & 0.666 \\
\hline $\begin{array}{c}\text { Elapsed time from the onset of } \\
\text { veraison to maturity (days) }\end{array}$ & $23.2(0.4)$ & $34.6(5.4)$ & 27.7(3.7) & $37.7(2.9)$ & $42.6(2.7)$ & $51.3(3.0)$ & 0.015 & $<0.001$ & 0.074 \\
\hline $\begin{array}{l}\text { Elapsed time from fruit set to } \\
\text { maturity (days) }\end{array}$ & $64.5(1.0)$ & $76.0(5.7)$ & $70.6(3.5)$ & $77.7(3.4)$ & $82.4(2.4)$ & $91.6(2.8)$ & 0.010 & $<0.001$ & 0.113 \\
\hline Leaf area $\left(\mathrm{dm}^{2}\right.$ plant $\left.^{-1}\right)$ & $13.5(0.7)$ & $13.5(1.2)$ & $13.5(0.5)$ & $5.4(0.6)$ & $4.6(0.5)$ & $4.4(0.2)$ & 0.748 & $<0.001$ & 0.739 \\
\hline Leaf dry matter $\left(\right.$ g plant $\left.^{-1}\right)$ & $8.8(0.8)$ & 10.1(1.1) & $10.2(0.5)$ & $3.7(0.4)$ & $3.6(0.4)$ & $3.5(0.2)$ & 0.556 & $<0.001$ & 0.348 \\
\hline Internodal length $(\mathrm{cm})$ & $8.0(0.3)$ & $7.0(0.6)$ & $6.6(0.3)$ & $3.9(0.3)$ & $2.8(0.2)$ & $2.9(0.2)$ & 0.001 & $<0.001$ & 0.723 \\
\hline
\end{tabular}


Table 2. Chlorophyll (Chl) and carotenoid concentrations and de-epoxidation state (DES) of xantophyll cycle in leaves of plants grown under $0,5.98$ and 9.66 $\mathrm{kJ} \mathrm{m}^{-2} \mathrm{~d}^{-1}$, well watered and water deficit, at maturity. Values are means $(\mathrm{n}=6)$ and standard errors. Main effects of UV-B $\left(P_{(U V-B)}\right)$, water availability $\left(P_{(\text {WA })}\right)$ and interaction between UV-B and water availability $\left(P_{(U V-B \times W A)}\right)$. In case of significant interaction between factors, different letters within the same parameter indicate significant differences $(p<0.05)$ according to LSD test.

\begin{tabular}{|c|c|c|c|c|c|c|c|c|c|}
\hline & \multicolumn{3}{|c|}{ Well Watered } & \multicolumn{3}{|c|}{ Water Deficit } & \multirow[b]{2}{*}{$P_{(U V-B)}$} & \multirow[b]{2}{*}{$P_{\text {(WA) }}$} & \multirow[b]{2}{*}{$P_{\left(U V^{*} W A\right)}$} \\
\hline & $0 \mathrm{~kJ} \mathrm{~m}^{-2} \mathrm{~d}^{-1}$ & $5.98 \mathrm{~kJ} \mathrm{~m}^{-2} \mathrm{~d}^{-1}$ & $9.66 \mathrm{~kJ} \mathrm{~m}^{-2} \mathrm{~d}^{-1}$ & $0 \mathrm{~kJ} \mathrm{~m}^{-2} \mathrm{~d}^{-1}$ & $5.98 \mathrm{~kJ} \mathrm{~m}^{-2} \mathrm{~d}^{-1}$ & $9.66 \mathrm{~kJ} \mathrm{~m}^{-2} \mathrm{~d}^{-1}$ & & & \\
\hline $\mathrm{Chl} \mathrm{a+b}\left(\mu \mathrm{mol} \mathrm{m}{ }^{-2}\right)$ & $602.7(25.8)$ & $581.3(24.1)$ & $501.8(34.1)$ & $557.3(45.5)$ & $720.8(34.8)$ & $638.0(64.6)$ & 0.114 & 0.029 & 0.050 \\
\hline $\mathrm{Chl} \mathrm{a+b}\left(\mu \mathrm{mol} \mathrm{g}{ }^{-1} \mathrm{DW}\right)$ & $8.21(0.54)$ & $8.54(0.60)$ & $7.22(0.39)$ & $9.00(0.45)$ & $8.31(0.49)$ & $8.94(0.40)$ & 0.543 & 0.064 & 0.147 \\
\hline Chla/Chlb & $2.96(0.04)$ & $3.04(0.03)$ & $3.12(0.06)$ & $3.09(0.03)$ & $3.02(0.05)$ & $3.01(0.07)$ & 0.686 & 0.986 & 0.056 \\
\hline$\beta$-Carotene $\left(\mathrm{mmol} \mathrm{mol}^{-1} \mathrm{Chl}\right)$ & $88.9(1.2) a b$ & $86.5(1.0) b$ & $91.5(1.3) \mathrm{a}$ & $85.8(1.3) b$ & $89.9(1.1)$ a & $88.6(1.2) a b$ & 0.092 & 0.539 & 0.012 \\
\hline Neoxanthin (mmol mol $\left.{ }^{-1} \mathrm{Chl}\right)$ & $43.1(0.03) \mathrm{a}$ & $41.2(0.9) \mathrm{ab}$ & $41.8(0.6) \mathrm{ab}$ & $40.1(0.8) b$ & $42.6(1.0) \mathrm{a}$ & $42.7(0.7) \mathrm{a}$ & 0.742 & 0.838 & 0.026 \\
\hline Lutein $\left(\mathrm{mmol} \mathrm{mol}{ }^{-1} \mathrm{Chl}\right)$ & $138.9(1.0) a b$ & $130.7(3.3) b$ & $135.5(1.9) a b$ & $132.9(4.6) \mathrm{ab}$ & $139.5(1.6) \mathrm{a}$ & $134.6(3.3) \mathrm{ab}$ & 0.953 & 0.791 & 0.042 \\
\hline Violaxanthin $(\mathrm{V})\left(\mathrm{mmol} \mathrm{mol}^{-1} \mathrm{Chl}\right)$ & $57.1(3.5)$ & $53.1(1.2)$ & $55.2(3.2)$ & $52.3(5.7)$ & $59.9(2.1)$ & $56.9(2.4)$ & 0.845 & 0.544 & 0.208 \\
\hline Antheraxanthin $(\mathrm{A})\left(\mathrm{mmol} \mathrm{mol}{ }^{-1} \mathrm{Chl}\right)$ & $7.0(0.4)$ & $6.4(1.3)$ & $8.5(1.2)$ & $10.1(2.5)$ & $6.8(0.6)$ & $6.0(0.5)$ & 0.293 & 0.751 & 0.121 \\
\hline Zeaxanthin (Z) (mmol mol $\left.{ }^{-1} \mathrm{Chl}\right)$ & $5.6(0.5) a b$ & $6.0(1.4) a b$ & $9.7(2.2) a b$ & $10.1(2.7) \mathrm{a}$ & $6.8(0.8) a b$ & $5.2(1.1) b$ & 0.628 & 0.831 & 0.032 \\
\hline $\mathrm{V}+\mathrm{A}+\mathrm{Z}\left(\mathrm{mmol} \mathrm{mol}^{-1} \mathrm{Chl}\right)$ & $69.6(3.6)$ & $67.3(1.6)$ & $73.4(2.2)$ & $72.5(7.0)$ & $73.0(1.9)$ & $68.0(2.9)$ & 0.970 & 0.721 & 0.311 \\
\hline $\operatorname{DES}(A+Z) /(V+A+Z)$ & $0.18(0.01) a b$ & $0.18(0.03) a b$ & $0.25(0.04) a b$ & $0.28(0.06) a$ & $0.18(0.02) a b$ & $0.16(0.02) b$ & 0.405 & 0.901 & 0.048 \\
\hline
\end{tabular}


Table 3. Total soluble proteins (TSP), lipid peroxidation, determined as thiobarbituric acid reacting substances (TBARS) concentration, superoxide dismutase (SOD), guaiacol peroxidase (GPX), catalase (CAT) and ascorbate peroxidase (APX) activities in leaves of plants grown under $0,5.98$ and $9.66 \mathrm{~kJ} \mathrm{~m}^{-2} \mathrm{~d}^{-1}$ of UV-B, well watered and water deficit, at maturity. Values are means $(n=5)$ and standard errors. Main effects of UV-B $\left(P_{(U V-B)}\right)$, water availability $\left(P_{(W A)}\right)$ and interaction between UV-B and water availability $\left(P_{(U V-B \times W A)}\right)$.

\begin{tabular}{|c|c|c|c|c|c|c|c|c|c|}
\hline & \multicolumn{3}{|c|}{ Well Watered } & \multicolumn{3}{|c|}{ Water Deficit } & \multirow[b]{2}{*}{$\boldsymbol{P}_{(U V-B)}$} & \multirow[b]{2}{*}{$P_{(\text {(W) }}$} & \multirow[b]{2}{*}{$\boldsymbol{P}_{\text {(UV'WA) }}$} \\
\hline & $0 \mathrm{~kJ} \mathrm{~m}^{-2} \mathrm{~d}^{-1}$ & $5.98 \mathrm{~kJ} \mathrm{~m}^{-2} \mathrm{~d}^{-1}$ & $9.66 \mathrm{~kJ} \mathrm{~m}^{-2} \mathrm{~d}^{-1}$ & $0 \mathrm{~kJ} \mathrm{~m}^{-2} \mathrm{~d}^{-1}$ & $5.98 \mathrm{~kJ} \mathrm{~m}^{-2} \mathrm{~d}^{-1}$ & $9.66 \mathrm{~kJ} \mathrm{~m}^{-2} \mathrm{~d}^{-1}$ & & & \\
\hline $\operatorname{TSP}\left(\mathrm{mg} \mathrm{m}^{-2}\right)$ & $8.6(0.1)$ & $9.8(0.6)$ & $10.9(0.2)$ & $12.1(0.01)$ & $12.8(1.0)$ & $14.3(0.2)$ & 0.145 & 0.001 & 0.969 \\
\hline TSP ( $\left.\mathrm{mg} \mathrm{g}^{-1} \mathrm{DW}\right)$ & $12.0(0.18)$ & $13.4(0.85)$ & $15.1(1.60)$ & 18.9(2.24) & $16.2(1.22)$ & 19.8(2.18) & 0.232 & 0.001 & 0.445 \\
\hline TBARS (nmol MDA g ${ }^{-1} \mathrm{DW}$ ) & $130.1(36.9)$ & $98.3(11.2)$ & $87.3(5.1)$ & $94.7(8.8)$ & $92.6(14.6)$ & 106.4(34.1) & 0.412 & 0.692 & 0.485 \\
\hline SOD (USOD mg $\left.{ }^{-1} \mathrm{~g}^{-1} \mathrm{DW} \mathrm{min}^{-1}\right)$ & $380.9(43.9)$ & $840.6(52.2)$ & $850.1(42.6)$ & $526.8(64.3)$ & $842.9(70.6)$ & $943.1(39.2)$ & $<0.001$ & 0.080 & 0.413 \\
\hline GPX (nmol guaiacol g-1 DW min $\left.{ }^{-1}\right)$ & $31.3(8.3)$ & $28.6(6.8)$ & $30.1(9.4)$ & $23.7(6.1)$ & $32.3(6.4)$ & $41.3(11.2)$ & 0.577 & 0.683 & 0.538 \\
\hline CAT (mmol H${ }_{2} \mathrm{O}_{2} \mathrm{~g}^{-1}$ DW $\left.\mathrm{min}^{-1}\right)$ & $2.48(0.52)$ & $2.59(0.16)$ & $2.37(0.37)$ & $2.33(1.08)$ & $2.07(0.46)$ & $2.28(1.02)$ & 0.583 & 0.002 & 0.051 \\
\hline APX ( $\left(\mu \mathrm{mol}\right.$ asc $\left.\mathrm{g}^{-1} \mathrm{DW} \mathrm{min}^{-1}\right)$ & $15.0(1.62)$ & $16.9(3.4)$ & $14.8(1.96)$ & $13.8(1.1)$ & $12.7(1.2)$ & $12.8(1.6)$ & 0.889 & 0.131 & 0.742 \\
\hline
\end{tabular}



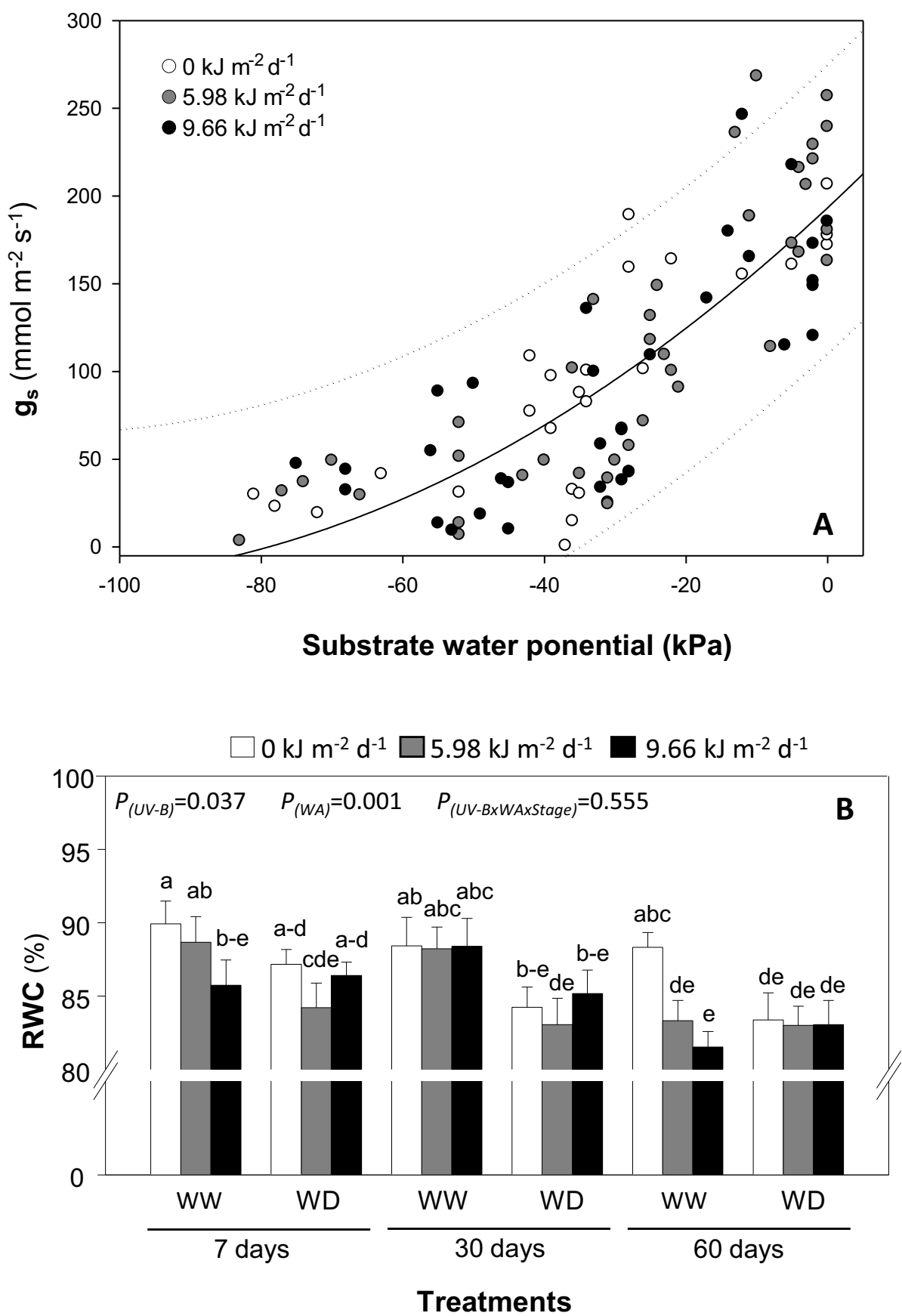

Figure 1 
$\square 0 \mathrm{~kJ} \mathrm{~m}^{-2} \mathrm{~d}^{-1} \square 5.98 \mathrm{~kJ} \mathrm{~m}^{-2} \mathrm{~d}^{-1} \square 9.66 \mathrm{~kJ} \mathrm{~m}^{-2} \mathrm{~d}^{-1}$

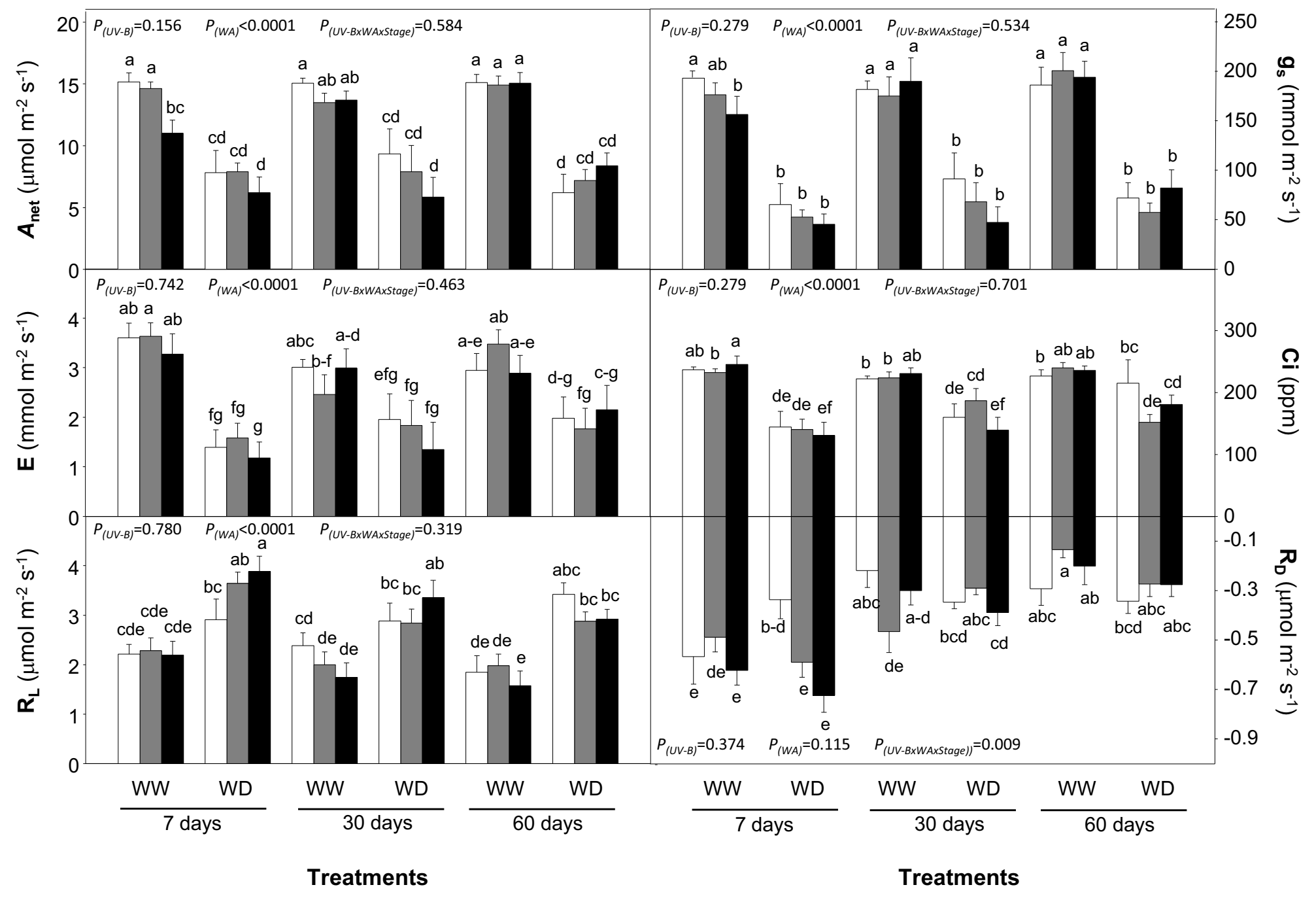

Figure 2 
$\square 0 \mathrm{~kJ} \mathrm{~m}^{-2} \mathrm{~d}^{-1} \square 5.98 \mathrm{~kJ} \mathrm{~m}^{-2} \mathrm{~d}^{-1} \square 9.66 \mathrm{~kJ} \mathrm{~m}^{-2} \mathrm{~d}^{-1}$

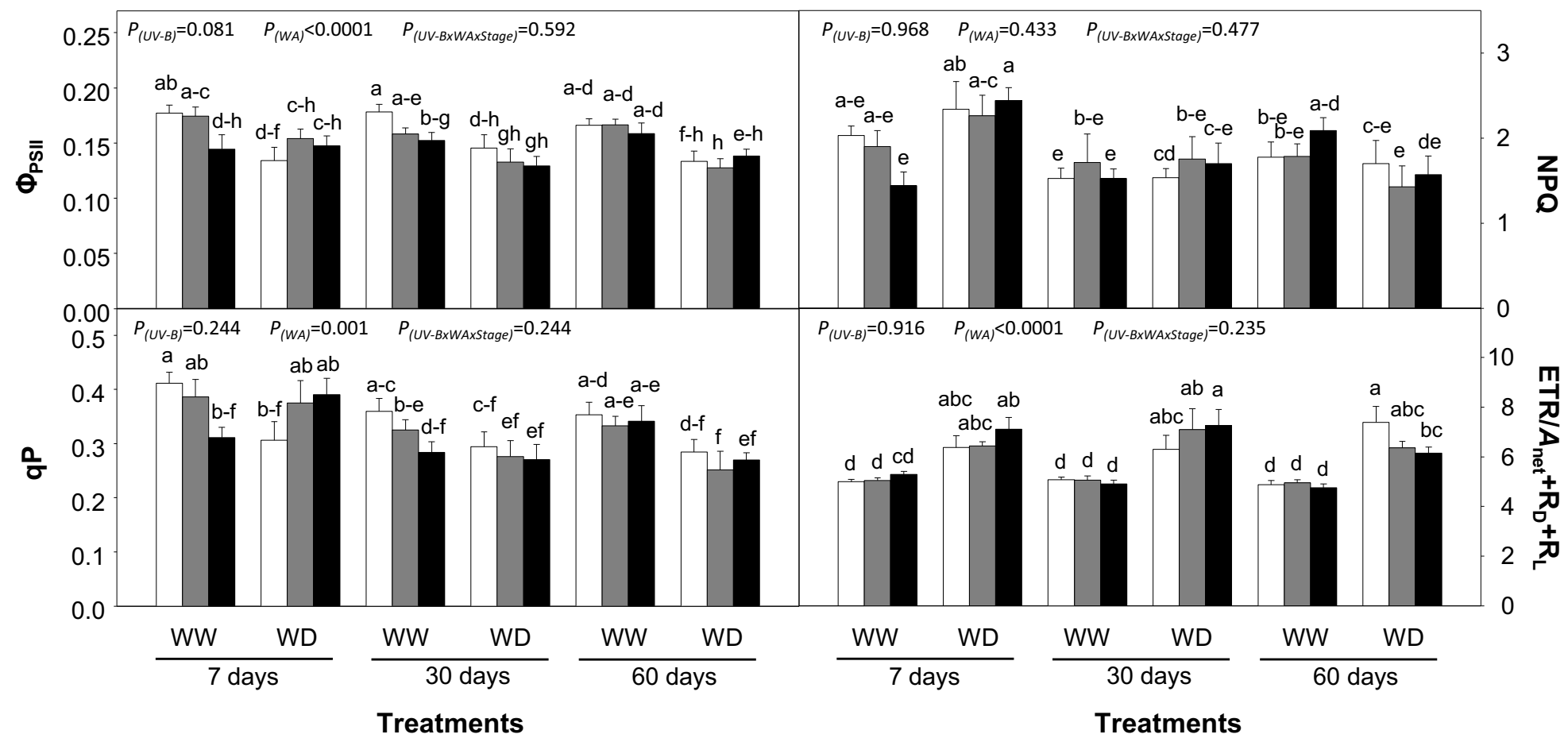

Figure 3 


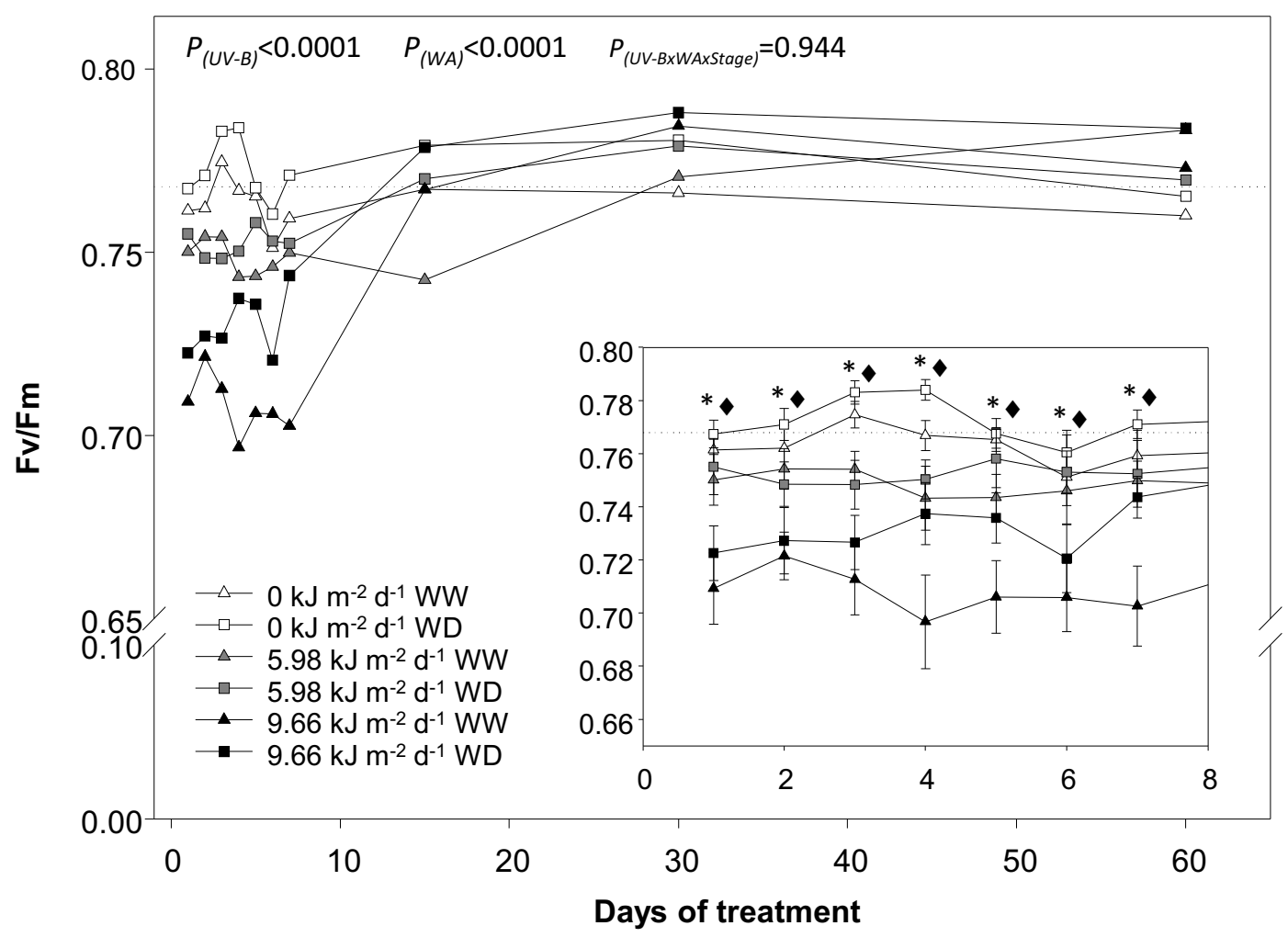

Figure 4 


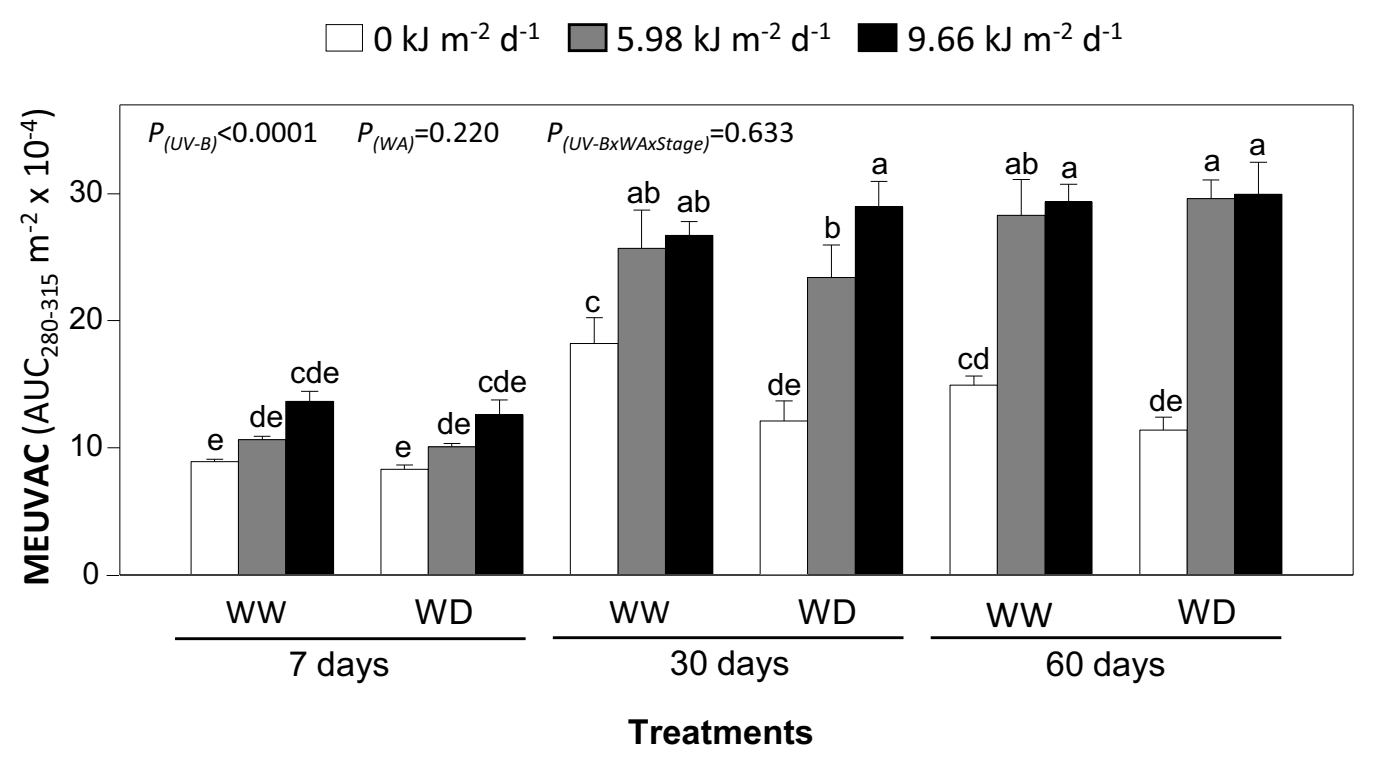

Figure 5 


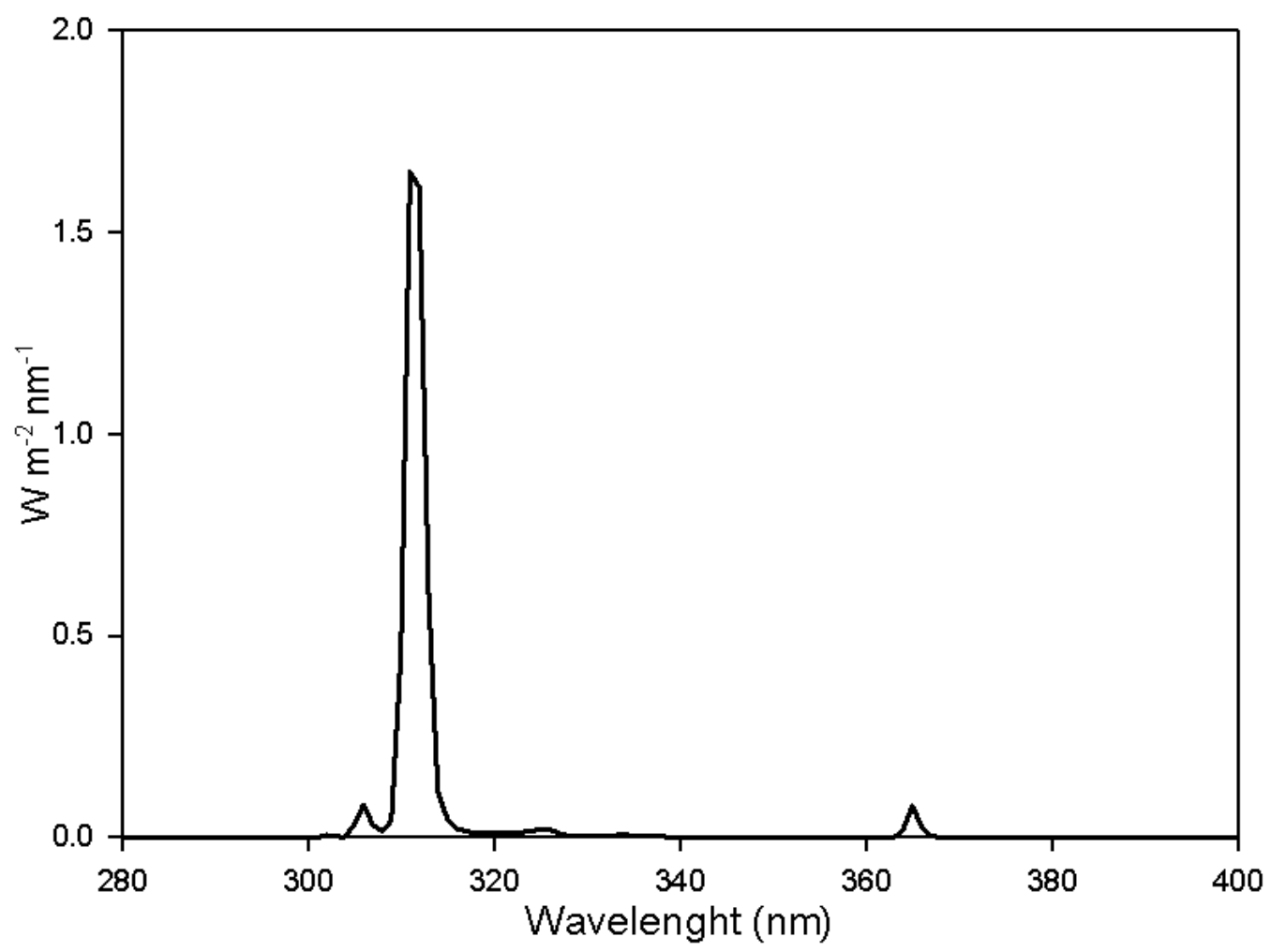

Figure S1. Spectral irradiance of the lamps used as UV-B source 


\section{Highlights}

UV-B and water deficit had little interactive effects on grapevine photosynthesis performance

The impact of UV-B on leaf photosynthesis was overshadowed by the effects of water deficit

Deficit irrigation did not modify the adaptive response of grapevine to UV-B radiation

UV-B and water deficit caused additive effects delaying the phenological development of grape berries 